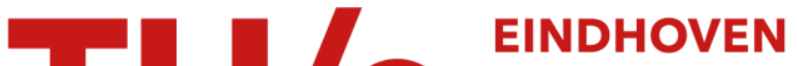 UNIVERSITY OF TECHNOLOGY
}

\section{Large volume injection in capillary GC using PTV injectors: Comparison of inertness of packing materials}

Citation for published version (APA):

Mol, J. G. J., Hendriks, P. J. M., Janssen, J. G. M., Cramers, C. A. M. G., \& Brinkman, U. A. T. (1995). Large volume injection in capillary GC using PTV injectors: Comparison of inertness of packing materials. Journal of High Resolution Chromatography, 18(2), 124-128. https://doi.org/10.1002/jhrc.1240180213

DOI:

10.1002/jhrc. 1240180213

Document status and date:

Published: 01/01/1995

\section{Document Version:}

Publisher's PDF, also known as Version of Record (includes final page, issue and volume numbers)

\section{Please check the document version of this publication:}

- A submitted manuscript is the version of the article upon submission and before peer-review. There can be important differences between the submitted version and the official published version of record. People interested in the research are advised to contact the author for the final version of the publication, or visit the $\mathrm{DOI}$ to the publisher's website.

- The final author version and the galley proof are versions of the publication after peer review.

- The final published version features the final layout of the paper including the volume, issue and page numbers.

Link to publication

\section{General rights}

Copyright and moral rights for the publications made accessible in the public portal are retained by the authors and/or other copyright owners and it is a condition of accessing publications that users recognise and abide by the legal requirements associated with these rights.

- Users may download and print one copy of any publication from the public portal for the purpose of private study or research.

- You may not further distribute the material or use it for any profit-making activity or commercial gain

- You may freely distribute the URL identifying the publication in the public portal.

If the publication is distributed under the terms of Article $25 \mathrm{fa}$ of the Dutch Copyright Act, indicated by the "Taverne" license above, please follow below link for the End User Agreement:

www.tue.nl/taverne

Take down policy

If you believe that this document breaches copyright please contact us at:

openaccess@tue.nl

providing details and we will investigate your claim. 


\title{
Large Volume Injection in Capillary GC Using PTV Injectors: Comparison of Inertness of Packing Materials
}

\author{
Hans G.J. Mol*, Pieter J.M. Hendriks, Hans-Gerd Janssen, and Carel A. Cramers \\ Eindhoven University of Technology, Laboratory of Instrumental Analysis, P.O. Box 513, 5600 MB Eindhoven, The Netherlands
}

Udo A.Th. Brinkman

Free University, Department of Analytical Chemistry, De Boelelaan 1083, 1081 HV Amsterdam, The Netherlands

\section{Key Words:}

\author{
Large volume injection \\ PTV injector \\ PTV solvent split injection \\ Packed inserts \\ Thermal degradation
}

\section{Introduction}

Programmed temperature vaporizing injectors (PTV) have been shown to be eminently suited for large volume sample introduction in capillary gas chromatography [1-3]. Large volume injection can be applied in trace analysis to improve analyte detectability. Very often it can replace an off-line evaporation step carried out to concentrate a diluted sample extract. In a recent paper we demonstrated that, for sample volumes up to $150 \mu \mathrm{l}$, the procedure for large volume injection is very simple when using PTV injectors equipped with liners with internal diameters larger than ca $2.5 \mathrm{~mm}$ [4]. With the split valve open and at a liner temperature below the solvent boiling point the sample can be rapidly injected, either manually or with an autosampler equipped with a large volume syringe. The solvent is vented via the split exit while the analytes are retained in the liner. After the solvent elimination step the analytes are transferred to the column in the splitless mode.

For large volume sampling with PTV injectors the liner has to be packed in order to retain the liquid sample after injection. In the above mentioned paper silylated glass wool was used as packing material. With liners packed with glass wool reliable results can be obtained for thermostable compounds such as polycyclic aromatic hydrocarbons and polychlorobiphenyls. For thermolabile compounds, and also for polar analytes, interaction with active sites on the glass wool surface may lead to degradation or adsorption of the analytes in the liner, as is also known from (PTV) split/splitless injection [5-7]. The aim of this work is to find alternatives for glass wool as packing material for use in large volume sampling with PTV injectors. Aspects that will be discussed are the sample volume that is retained by the packed liner, and the inertness and thermostability of the packing material.

\section{Experimental}

\subsection{Materials and Reagents}

Silanized glass wool was obtained from Perkin Elmer (Norwalk, CT, USA). Quartz wool, glass beads (60-80 mesh), Tenax TA (35-60 mesh) and Dexsil-300 (12\% coated on Chromosorb 750, 80-100 mesh) were purchased from Chrompack (Bergen op
Zoom, The Netherlands). PTFE (Teflon) and polyimide wool were made in house from PTFE and polyimide rods obtained from Eriks (Alkmaar, The Netherlands). Reagents used for deactivation of the liners, bis-(trimethylsilyl)amine (HMDS) and polymethylhydrosiloxane (PMHS, PS122) were from Pierce Chemical Co. (Rockford, IL, USA) and Petrarch Systems (Bristol, PN, USA), respectively. All solvents were freshly distilled before use. For the Donike test mixture, fatty acids were silylated with bistrimethylsilyltrifluoracetamide (BSTFA) as described elsewhere [4]. A second test mixture, containing 27 compounds (names are indicated in the figures/tables), was made in ethyl acetate. For large volume injections this sample was diluted in hexane or pentane.

\subsection{Instrumentation}

A Hewlett-Packard 5890A (Avondale, PA, USA) gas chromatograph equipped with a flame ionization detector and a PTV injector (Optic, Ai Cambridge, Cambridge, UK) was used. The injector could be cooled to sub-ambient temperatures with carbon dioxide. GC separation was performed on a $25 \mathrm{~m} \times 0.32 \mathrm{~mm}$ i.d. column coated with a $0.17 \mu \mathrm{m}$ Ultra- 2 stationary phase (HewlettPackard). Helium was used as the carrier gas at an inlet pressure of $100 \mathrm{kPa}$. The split flow was $250 \mathrm{ml} / \mathrm{min}$. All injections were carried out manually. For large volume injection the sample was rapidly injected, i.e. within 1-3 s. After solvent elimination the PTV was heated at $8 \%$ to $300{ }^{\circ} \mathrm{C}$ or the maximum operation temperature of the liner used. The splitless time was $1.5 \mathrm{~min}$ for the empty liner, the glass wool and quartz wool liners. For the other liners a splitless time of 2.5 min was used. On-column injection was possible using a special on-column insert for the PTV injector. In case of on-column injection the PTV was heated at $1 \%$. The GC temperature programme used for all separations was as follows: $40^{\circ} \mathrm{C}(1 \mathrm{~min})$ with $20^{\circ} / \mathrm{min}$ to $300^{\circ} \mathrm{C}(5 \mathrm{~min})$.

\subsection{Liners, Deactivation and Conditioning}

For splitless and large volume injections packed liners or a specially designed 'cup' liner (made in house) were used (Figure 1). To keep the packing material in place, a glass frit was made in the lower part of the $80 \mathrm{~mm} \times 3.4 \mathrm{~mm}$ i.d. liners. This frit has a small surface and replaces the plug of glass wool normally used. Deactivation and conditioning of the liners was done inside the 


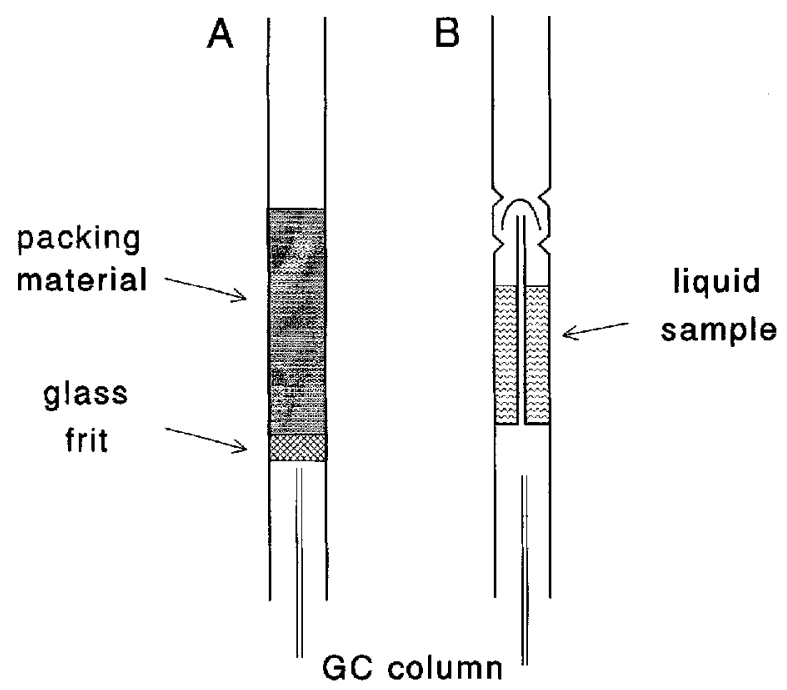

Figure 1. Liners used in this work: A) packed liner, B) cup liner.

injector. During these procedures the column was replaced by a $8 \mathrm{~m}$ piece of $0.32 \mathrm{~mm}$ i.d. fused silica. Before packing, the empty liners were deactivated by injecting 10 times $1 \mu 1$ of neat HMDS at $130^{\circ} \mathrm{C}$ while applying a low flow of helium (split valve closed). Quartz wool was deactivated by rinsing the packed liner with a $1 \% \mathrm{w} / \mathrm{w}$ solution of PMHS in pentane. The liner was then placed in the injector and after purging with a low flow of helium for 5 min heated to $290^{\circ} \mathrm{C}$ for two hours. The cup liner was deactivated in the same way. For all packed liners the length of the packed bed was $25 \mathrm{~mm}$. For conditioning the Tenax, Dexsil, PTFE and polyimide packings, the packed liners were first purged for 10 min with a high helium flow and then heated to the maximum operation temperature (see below) for 30-60 min.

\section{Results and Discussion}

The use of glass wool as packing material in large volume sample introduction using PTV injectors can have two disadvantages. The more important one is that glass wool is difficult to deactivate in such a way that thermal degradation of labile analytes and adsorption of polar analytes is completely prevented. Further, liners cannot be packed with glass wool in a reproducible way which may result in varying maximum sample volumes and solvent vent times [4]. For these reasons, several other packing materials were evaluated as alternatives for glass wool. Ideally, the packing should be highly inert and thermostable. The packed liner should not retain the high-boiling analytes too strong in order to minimize the thermal stress applied to these compounds upon splitless transfer to the column. Furthermore, the packing should be compatible with common organic solvents and the inertness should not be affected by water. A good water resistance of the liner is beneficial for long-term stability when 'wet' extracts (i.e. ethyl acetate) or aqueous samples are introduced. Finally, the packed liner should retain a large volume of liquid sample in order to allow rapid introduction of large sample volumes without overloading the liner with liquid. Several packing materials were selected for this study. Untreated quartz wool and silanized glass wool were included in order to find out for which (classes of) compounds insufficient liner inertness causes problems. An attempt was made to deactivate quartz wool. A support coated with Dexsil was chosen because of its high ther- mostability (known from high-temperature GC with packed columns). Polymer materials were selected based on their water resistance. Finally, a special 'cup' liner, designed to retain the liquid sample without the need of using a packing, was also tested. The total area of potential active glass surface for this liner is similar to that of a straight empty liner, which has proven to yield the best results for splitless injection of labile compounds.

For the cup liner and the seven packed liners the maximum sample volume that could be rapidly injected without flooding the liner was determined as described earlier [4]. The results are summarized in Table 1. The table shows that more than $100 \mu \mathrm{l}$ can be rapidly injected when using the cup liner, the quartz or glass wool packed liners, or the Tenax liner. For liners packed with glass beads sample volumes of less than $50 \mu \mathrm{l}$ already caused overloading. These liners were therefore not included in our further studies. For an evaluation of the thermostability of the liners packed with a polymer material or with the Dexsil phase, the maximum operation temperatures of these liners were determined after conditioning. The results are included in Table 1. The criterion was that for a blank run, applying a splitless time of $2.5 \mathrm{~min}$, no peaks corresponding to an FID response of $0.5 \mathrm{ng}$ of an n-alkane should be observed. The Dexsil liner showed the best thermostability. Actually, good blanks were still obtained at $360{ }^{\circ} \mathrm{C}$. During conditioning at this temperature, however, a substantial part of the Dexsil phase was removed from the support. This was discovered during experiments in which the temperatures required for efficient splitless transfer were determined, i.e. after exposing the material to a temperature of $360^{\circ} \mathrm{C}$, the final PTV temperatures needed for quantitative splitless transfer within 2.5 min were found to be lower.

Table 1. Liner characteristics.

\begin{tabular}{lll}
\hline Liner/packing material & $\mathrm{V}_{\max }(\mu \mathrm{l})^{\mathrm{a})}$ & $\mathrm{T}_{\max }\left({ }^{\circ} \mathrm{C}\right)$ \\
\hline Glass wool & 115 & - \\
Quartz wool & 125 & - \\
Glass beads & 40 & - \\
Cup liner & 150 & - \\
PTFE wool & 80 & 275 \\
polyimide wool & 80 & 275 \\
Tenax TA & 125 & 310 \\
Dexsil-coated support & 80 & 340 \\
\hline
\end{tabular}

a) $V_{\max }$ is the maximum volume that can be injected rapidly.

The inertness of the liners was evaluated using two test mixtures: the Donike test mixture [8], containing trimethylsilyl esters of fatty acids, and a test mixture of 27 compounds which vary widely in polarity, volatility, and stability. Peak areas obtained for $1 \mu \mathrm{l}$ splitless injections were compared with those obtained for oncolumn injections. To distinguish between activity of the packing material and residual activity of the liner itself, the measurements were also carried out with a liner containing only the glass frit. The silyl esters of the Donike mixture can degrade due to hydrolytic activity of the liner. Silanol groups are generally thought to be responsible for this phenomenon [8]. The recoveries of the silyl esters, relative to on-column injection, are given in Table 2. In general, for less volatile esters degradation is more pronounced because they leave the PTV liner at a higher temperature. High 
Table 2. Recovery of trimethylsilyl esters of fatty acids obtained after cold splitless injection ${ }^{\text {a) }}$ relative to on-column injection.

\begin{tabular}{lrrrr}
\hline & \multicolumn{4}{c}{ Recovery (\%) } \\
Liner/packing material & E10 & E14 & E18 & E22 \\
\hline Empty liner with frit & 103 & 103 & 97 & 82 \\
Silylated glass wool & 58 & 10 & 0 & 0 \\
Quartz wool (untreated) & 3 & 0 & 0 & 0 \\
Quartz wool (PMHS deact.) & 102 & 96 & 83 & 35 \\
Cup liner & 98 & 102 & 90 & 69 \\
PTFE wool & 105 & 103 & 97 & 54 \\
Polyimide wool & 100 & 99 & 77 & 13 \\
Tenax TA & 102 & 100 & 98 & 81 \\
Dexsil (360 & 103 & 100 & 80 & 33 \\
Dexsil $\left(320^{\circ} \mathrm{C}\right)^{\mathrm{d})}$ & 103 & 103 & 99 & 90 \\
\hline
\end{tabular}

a) $2 \mu 1$ injection, concentration: $10 \mu \mathrm{g} / \mathrm{ml} .{ }^{\text {b) }} \mathrm{E} 10=$ trimethylsilylester of decanoic acid, etc. ${ }^{\mathrm{c})}$ Liner conditioned at $360^{\circ} \mathrm{C}$. ${ }^{\text {d) }}$ Liner conditioned at $320^{\circ} \mathrm{C}$

recoveries are obtained for liners without a packing material, i.e. the empty liner and the cup liner. For the Dexsil liner conditioned at $320^{\circ} \mathrm{C}$, almost no degradation occurred. Conditioning at $360^{\circ} \mathrm{C}$ resulted in partial removal of the Dexsil phase which in turn resulted in an increase in liner activity towards the silyl esters. For the Tenax packed liner there was not much degradation of the silyl esters despite the fact that the compounds are probably quite strongly retained by this material. Untreated quartz wool caused virtually complete degradation of all esters. Silylation of the quartz wool may improve the inertness. However, based on the results obtained with silanized glass wool, it is expected that inertness will still be insufficient. Deactivation of quartz wool with PMHS was found to result in a significantly reduced decomposition of the silyl esters.

For a broader evaluation of the inertness of the various liners the mixture containing 27 test compounds was used. In Figure 2 the sum of the recoveries relative to on-column injection ( $\mathrm{sum}=$ 2700) is depicted for each liner. Apart from the empty liner, the
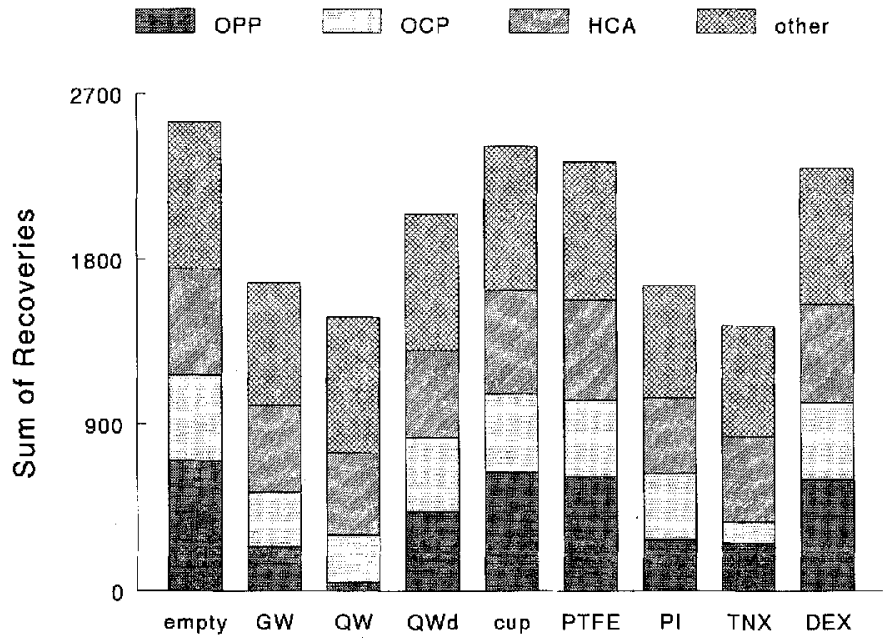

Figure 2. Sum of recoveries of 27 compounds (indicated in figure 3) obtained after cold splitless injection ( $1 \mu \mathrm{l} ; 5-10 \mu \mathrm{g} / \mathrm{ml}$ ) using different liners; recoveries are relative to on-column injection $(\mathrm{sum}=2700)$. $\mathrm{OPP}=$ organophosphorus pesticides; $\mathrm{OCP}=$ organochlorine pesticides; $\mathrm{HCA}=$ heterocyclic aromatic compounds. Liner/packing: $\mathrm{GW}=$ silanized glass wool; $\mathrm{QW}=$ quartz wool (not deactivated); QWd = quartz wool deactivated with PMHS; $\mathrm{PI}$ = polyimide wool; TNX = Tenax; DEX = support coated with Dexsil. cup liner and the liners packed with PTFE wool or Dexsil showed the best overall performance. In contrast to the situation for the silyl esters, the Dexsil liner was found to yield higher recoveries when conditioned at $360{ }^{\circ} \mathrm{C}$. The low overall recovery for the Tenax liner is partly due to strong adsorption of the less volatile compounds: for analytes up to caffein the recoveries were below $80 \%$ only for dinitrobenzene and dimethoate. Figure 3 illustrates the problems encountered when (silanized) glass wool is used as packing material. Compared with on-column injection the response for a number of analytes is much lower. The most critical compounds in the test mixture were found to be vamidothion and azinfos-methyl. Although relatively volatile, a reduced response was also found for dinitrobenzene with all packed liners. It has to be emphasized that for real samples the matrix can also affect degradation and adsorption of analytes in the injector. For pesticides, for example, responses obtained with real samples are often higher than for the same analytes dissolved in an organic solvent [9]. The reason for this is that matrix constituents shield active sites in the liner, thereby reducing adsorption/degradation of the pesticides. For very active liners the response will depend strongly on both the kind of matrix and the amount of matrix accumulated in the liner. It is expected that the use of inert liners will reduce these effects and therefore improve the reliability of
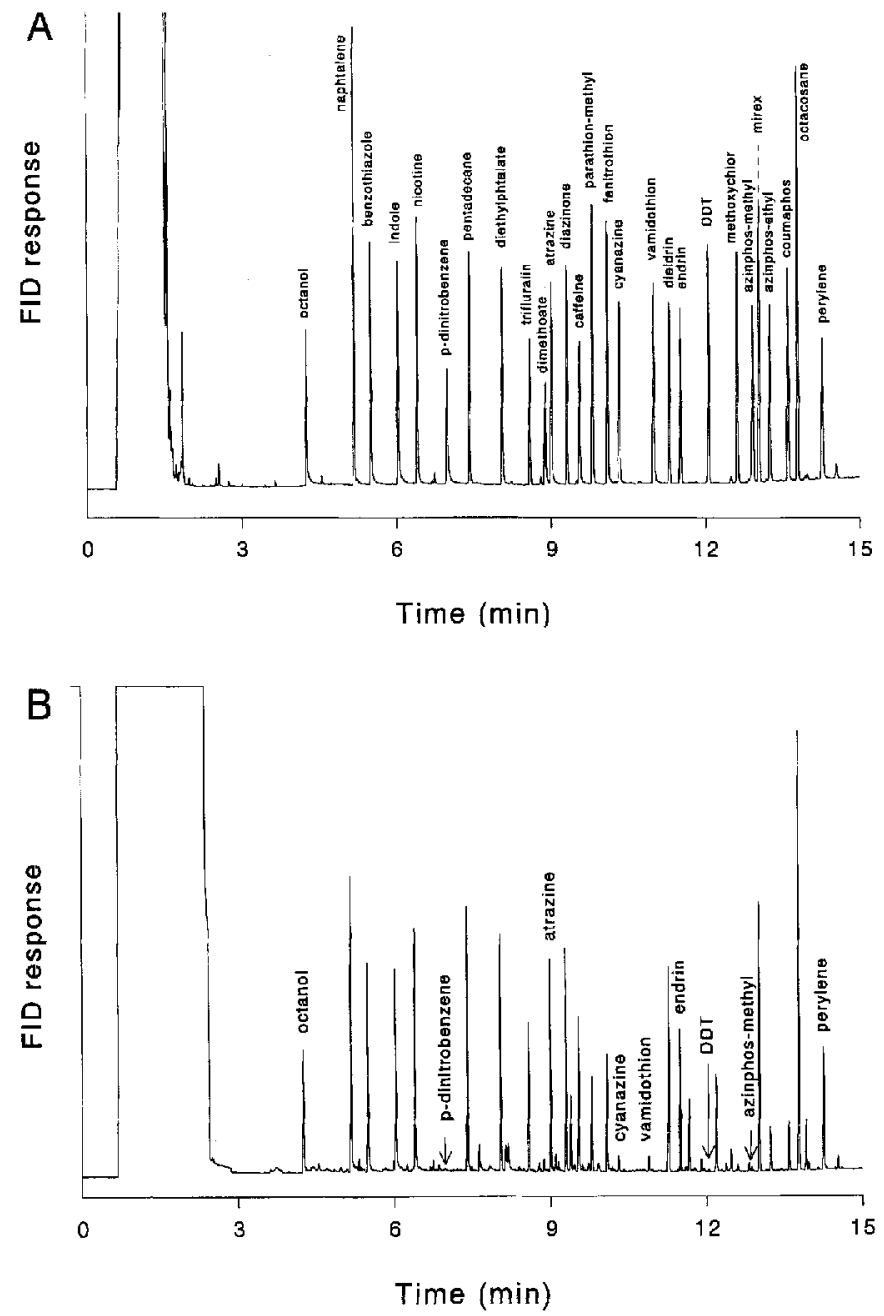

Figure 3. GC-FID chromatograms of $1 \mu$ injections of a standard containing 27 analytes (concentration, $5-10 \mu \mathrm{g} / \mathrm{ml}$ ). A) on-column injection, B) cold splitless injection using a liner packed with silanized glass wool. 
the analysis. Further experiments of evaluation were carried out for the four most inert liners as indicated by the recoveries obtained for splitless injection of both test mixtures. The maximum sample volume was not a decisive factor in the selection as these volumes did not differ by more than a factor of two.
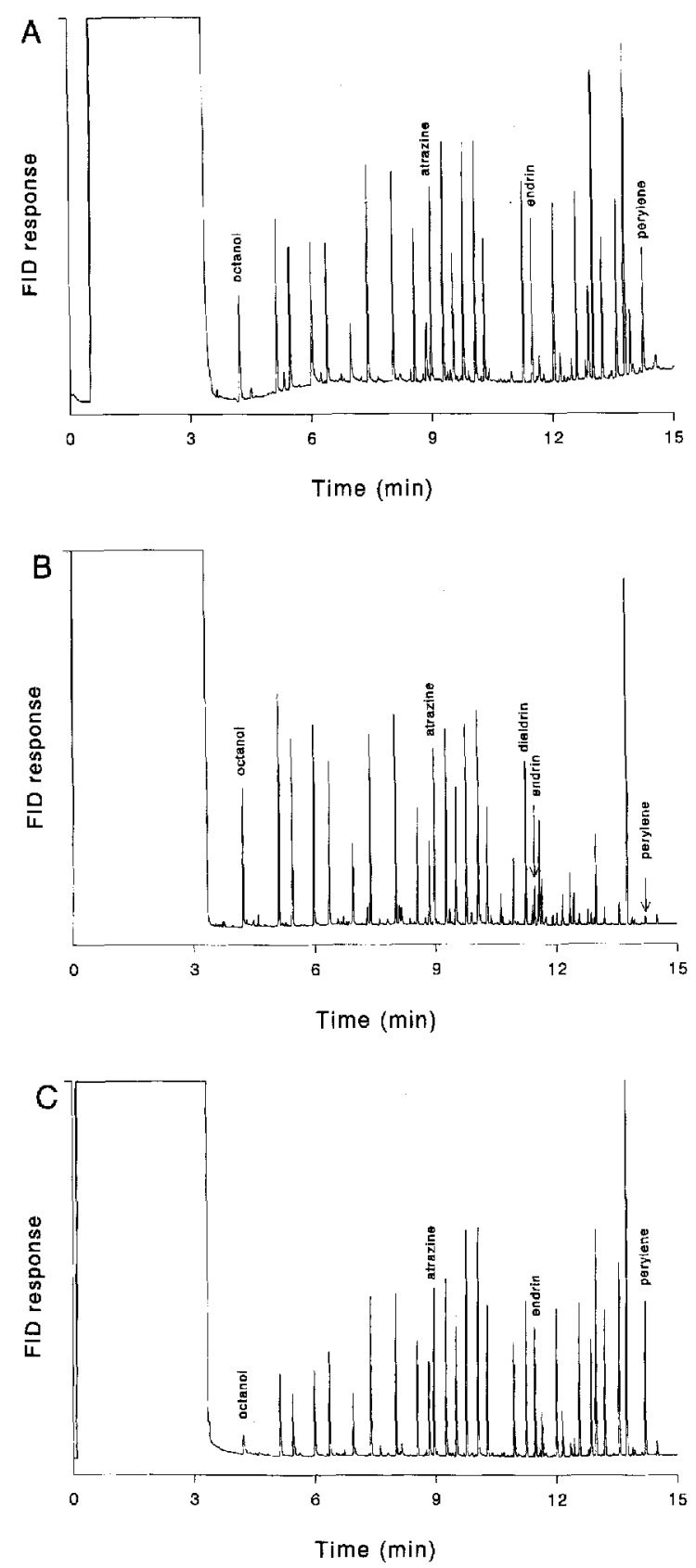

Figure 4. GC-FID chromatograms obtained after large volume injection using PTV injectors in the solvent split mode. Details/conditions: see Table 3. A) P'TFE wool packed liner, $60 \mu \mathrm{l}$ injection of a $8-16 \mathrm{ng} / \mathrm{ml}$ solution, B) Tenax packed liner, $100 \mu \mathrm{l} ; 50-100 \mathrm{ng} / \mathrm{ml}$, C) Cup liner, $100 \mu \mathrm{l} ; 50-100 \mathrm{ng} / \mathrm{ml}$.

For large volume sample introduction the mixture containing the 27 test compounds was diluted such that the amount of compound injected was the same as for the $1 \mu \mathrm{l}$ splitless injection described above. The diluted sample $(60-100 \mu \mathrm{l})$ was rapidly injected with the split valve open at an initial PTV temperature of 0 to $40^{\circ} \mathrm{C}$.
The solvent vent time was determined either by ignition of the vapors leaving the split exit or by monitoring with the FID detector (the same as used for analyte detection) as was described previously [4]. After solvent elimination the analytes trapped in the liner were transferred to the GC column in the splitless mode. The solvent elimination process for the cup liner is different from that of the packed liners. Firstly, the surface from which the solvent evaporates is much smaller and, secondly, the removal of solvent vapors by the carrier gas is very inefficient compared to the situation for packed beds. As a consequence, solvent evaporation was much slower and initial PTV temperatures close to the solvent boiling point had to be applied in order to obtain acceptable vent times.

In principle there are three causes for losses of analytes in large volume injection with PTV injectors: $i$ ) volatiles can be vented together with the solvent during solvent elimination, $i i$ ) high-boiling compounds can adsorb strongly onto the packing material which will complicate transfer to the GC column after solvent elimination, and iii) analytes can degrade in the liner. By choosing the correct liner losses due to the first two causes can be avoided. This is illustrated in Figure 4. When using the PTFE, or the Dexsil, packed liners at $0^{\circ} \mathrm{C}$, most analytes could be retained in the liner during solvent elimination and, next, desorbed rapidly during splitless transfer. When using the Tenax liner all analytes from the test mixture were quantitatively retained, even at a liner temperature of $30^{\circ} \mathrm{C}$, but compounds less volatile than endrin could not be desorbed at $310^{\circ} \mathrm{C}$ within $2.5 \mathrm{~min}$. For the cup liner losses of the more volatile analytes occur because relatively high initial PTV temperatures have to be used for solvent elimination. Moreover, beneficial effects for retaining analytes in the liner that do occur in packed beds, i.e. cooling by evaporation [4], are less efficient for the cup liner. With this liner, compounds more volatile than atrazine were partially vented with the solvent. Table 3 shows recoveries and relative standard deviations (RSD) for large volume injections of the test mixture diluted with hexane. The average recoveries for the Dexsil and the PTFE liners were found to be $c a 90 \%$. For 18 analytes the average recovery obtained with the cup liner (higher boiling analytes) and the Tenax liner (more volatile analytes) was also ca 90\%. As is to be expected, the overall recovery decreases when lower concentrations are injected. For the PTFE liner the average recovery decreased to $c a 80 \%$ when the sample was diluted a further 10 -fold, viz. 8 to $16 \mathrm{ng} / \mathrm{ml}$, and the RSD values increased (Table III and Figure 4A). However, with one exception (vamidothion), the results are quite acceptable regarding the trace-level concentrations used.

\section{Conclusions}

The use of (silylated) glass wool as packing material in large volume sample introduction with PTV injectors easily causes degradation of labile or polar compounds. In this work liners packed with several types of material and a specially designed 'cup' liner were evaluated as alternatives for glass wool packed liners. PTFE wool and a support coated with Dexsil were much more inert than glass wool and found to be suited as packing material in large volume sample introduction for analytes covering a broad volatility and polarity range. For samples containing relatively volatile analytes only, the liner packed with Tenax is especially suited. The cup liner is a good option when only higher boiling analytes are of interest. In other words, by selecting a 
Table 3. Percent recoveries (relative to on-column injection) of 27 compounds for large volume injection using the PTV injector in the solvent split mode.

\begin{tabular}{|c|c|c|c|c|c|c|c|c|c|c|}
\hline Liner/packing & \multicolumn{2}{|c|}{ Cup } & & & \multicolumn{2}{|c|}{ Dexsil } & \multicolumn{4}{|c|}{ PTFE } \\
\hline Sample volume $(\mu \mathrm{l})^{\mathrm{a})}$ & \multicolumn{2}{|c|}{100} & \multicolumn{2}{|c|}{100} & \multicolumn{2}{|c|}{60} & \multicolumn{2}{|c|}{60} & \multicolumn{2}{|c|}{60} \\
\hline Concentration $(\mathrm{ng} / \mathrm{ml})$ & \multicolumn{2}{|c|}{$50-100$} & \multicolumn{2}{|c|}{$50-100$} & \multicolumn{2}{|c|}{$80-160$} & \multicolumn{2}{|c|}{$80-160$} & \multicolumn{2}{|c|}{$8-16$} \\
\hline PTV temperature $\left({ }^{\circ} \mathrm{C}\right)$ & \multicolumn{2}{|c|}{40} & \multicolumn{2}{|c|}{30} & \multicolumn{2}{|c|}{0} & \multicolumn{2}{|c|}{0} & \multicolumn{2}{|c|}{0} \\
\hline Vent time (min) & \multicolumn{2}{|c|}{5.0} & \multicolumn{2}{|c|}{0.7} & \multicolumn{2}{|c|}{2.0} & \multicolumn{2}{|c|}{1.7} & \multicolumn{2}{|c|}{1.7} \\
\hline Compound & $\operatorname{Rec}^{\mathfrak{d})}$ & $R S D$ & Rec & $R S D$ & $\operatorname{Rec}$ & $R S D$ & $\operatorname{Rec}$ & $R S D$ & $\operatorname{Rec}$ & $R S D$ \\
\hline Octanol & 52 & 7.5 & 116 & 2.5 & 108 & 6.4 & 110 & 3.1 & 100 & 12 \\
\hline Naphthalene & 41 & 7.5 & 98 & 0.1 & 85 & 2.4 & 73 & 21 & 66 & 20 \\
\hline Benzothiazole & 47 & 4.9 & 103 & 0.6 & 90 & 2.1 & 88 & 5.5 & 88 & 5.3 \\
\hline Indole. & 54 & 12 & 99 & 0.2 & 90 & 2.6 & 94 & 2.3 & 86 & 5.3 \\
\hline Nicotine & 57 & 11 & 80 & 1.4 & 84 & 1.8 & 85 & 1.6 & 69 & 7.5 \\
\hline$p$-Dinitrobenzene & 57 & 11 & 65 & 0.7 & 56 & 2.3 & 84 & 1.9 & 58 & 6.0 \\
\hline Pentadecane & 78 & 13 & 100 & h) & 93 & 2.4 & 97 & 0.8 & 102 & 4.6 \\
\hline Diethylphtalate & 85 & 11 & 105 & 0.5 & 97 & 1.0 & 100 & 0.9 & 100 & 4.9 \\
\hline Trifluralin & 85 & 11 & 91 & 0.4 & 92 & 1.1 & 93 & 1.3 & 92 & 2.2 \\
\hline Dimethoate & 90 & 8.5 & 76 & 1.3 & 91 & 2.5 & 90 & 1.7 & 56 & 13 \\
\hline Atrazine & 91 & 8.6 & 97 & 1.6 & 92 & 0.9 & 94 & 2.2 & 86 & 1.4 \\
\hline Diazinone & 97 & 7.2 & 101 & 0.5 & 98 & 0.7 & 99 & 1.2 & 96 & 1.3 \\
\hline Caffeine & 99 & 2.8 & 99 & 0.8 & 98 & 1.2 & 95 & 2.0 & 80 & 1.5 \\
\hline Parathion-methyl & 86 & 5.2 & 82 & 1.0 & 91 & 1.4 & 93 & 1.3 & 80 & 3.5 \\
\hline Fenitrothion & 89 & 3.4 & 93 & 3.1 & 92 & 0.8 & 98 & 3.9 & 81 & 3.1 \\
\hline Cyanazine & 94 & 1.5 & 67 & 1.6 & 87 & 3.2 & 89 & 0.7 & 75 & 2.4 \\
\hline Vamidothion & 61 & 4.4 & 34 & 2.3 & 34 & 14 & 54 & 9.0 & 0 & - \\
\hline Dieldrin & 100 & e) & 98 & 1.5 & 100 & c) & 100 & c) & 100 & c) \\
\hline Endrin & 88 & 1.0 & 62 & 3.8 & 94 & 1.6 & 94 & 0.9 & 85 & 3.1 \\
\hline$p, p^{\prime}-\mathrm{DDT}$ & 67 & 2.7 & 7 & 8.4 & 82 & 2.9 & 86 & 0.2 & 69 & 2.4 \\
\hline Methoxychlor & 71 & 2.7 & 6 & 7.5 & 83 & 3.9 & 88 & 1.1 & 69 & 3.3 \\
\hline Azinfos-methyl & 64 & 3.4 & 7 & 8.6 & 70 & 3.5 & 71 & 2.1 & 52 & 5.6 \\
\hline Mirex & 91 & 1.6 & 35 & 7.7 & 100 & 0.8 & 99 & 1.4 & 100 & 1.7 \\
\hline Azinfos-Ethyl & 93 & 1.9 & 11 & 7.1 & 92 & 1.8 & 93 & 0.4 & 79 & 2.9 \\
\hline Coumaphos & 95 & 2.4 & 11 & 11 & 92 & 2.1 & 93 & 1.1 & 78 & 4.3 \\
\hline Octacosane & 111 & 1.8 & 99 & 2.0 & 100 & 1.2 & 101 & 1.3 & 101 & 1.4 \\
\hline Perylene & 107 & 2.9 & 6 & 1.6 & 93 & 2.2 & 89 & 4.0 & 86 & 9.0 \\
\hline
\end{tabular}

a) Solvent: cup liner: pentane; other liners: hexane. ${ }^{\text {b) }}$ Pentadecane used as internal standard. ${ }^{\text {c) }}$ Dieldrin used as internal standard.

${ }^{d)} \mathrm{Rec}=$ recovery and $R S D$ relative standard deviation $(\%)(n=3)$

PTV injector equipped with the proper liner, good recoveries and satisfactory RSD values can be obtained for a wide variety of analytes in large volume injection in GC.

\section{Acknowledgment}

The Foundation for Chemical Research in the Netherlands (SON) is gratefully acknowledged for their financial support (project No 700-344-009).

\section{References}

[1] W. Vogt, K. Jacob, and H.W. Obwexer, J. Chromatogr. 174 (1979) 437-439.

[2] J. Staniewski and J.A. Rijks, J. Chromatogr. 623 (1992) 105-113.

[3] J. Staniewski and J.A. Rijks, J. High Resol. Chromatogr. 16 (1993) 182-187.
[4] H.G.J, Mol, H.-G. Janssen, C.A. Cramers, and U.A.Th. Brinkman, J. High Resol. Chromatogr. 18 (1995) 19.

[5] G. Schomburg in 'Sample Introduction in Capillary Gas Chromatography', Vol. 1, P. Sandra (ed.), Huethig, Heidelberg, Germany, 1985.

[6] H.-M. Müller and H.-J. Stan, J. High Resol. Chromatogr. 13 (1990) 759-763.

[7] K. Grob and Ch. Wagner, J. High Resol. Chromatogr. 16 (1993) 464-468.

[8] M. Donike, Chromatographia 6 (1973) 190-195.

[9] D.R. Erney and C.F. Poole, J. High Res. Chromatogr. 16 (1993) 501-503. 